\section{Seasonal variations of Escherichia coli contamination in clams (Chamelea gallina) harvested in the Adriatic Sea (San Benedetto del Tronto district, Italy)}

\section{Cesare Ciccarelli, Angela Marisa Semeraro, Alessandra Aliventi, Vittoria Di Trani, Piero Capocasa}

Servizio Veterinario di Igiene degli Alimenti di Origine Animale - ASUR Marche, Area Vasta n. 5, San Benedetto del Tronto, Italy

\section{Abstract}

In the European Union, the classification of shellfish harvesting areas depends on levels of Escherichia coli checked in shellfish flesh and determines whether post-harvest treatment required before shellfish can be sold for human consumption. Nevertheless, intermittent sources of contamination, such as rainfall and runoff from agricultural and urban lands, may give rise to seasonal variations of $E$. coli concentration, hence an annual classification could not be correct. In this study, we investigated the microbial trend in clams (Chamelea gallina) harvested from the district of San Benedetto del Tronto, Italy. The Algaeadria database, a monitoring network for the whole Adriatic area, provided results from 2005 to 2012. E. coli values compliant and non-compliant with food safety criteria were evaluated by graphical data analysis tools and one-tailed Fisher's exact test. The results showed a clear general seasonal trend and, in one of the considered areas, the non-compliant values from July to February were significantly lower than those from March to June $(\mathrm{P}<0.05)$. These findings may scientifically support a seasonal classification.

\section{Introduction}

In the European Union, official controls on the production and distribution stages of live bivalve molluscs for human consumption include a sampling plan of production areas based on the study of contamination sources (sanitary survey), critical for the classification. The aim of the sanitary survey is the classification of areas in three classes, A, B or C. Bivalves harvested from class A areas may be placed on the market for direct human consumption; bivalves from class B areas must undergo purification; the ones from class $\mathrm{C}$ areas must be relayed over a long period (European Commission, 2004).

Natural beds of clams (Chamelea gallina) in the district of San Benedetto del Tronto (South Marche), hardly exploited for harvesting, have been recently reclassified (Marche Region, 2013) and three of the seven areas previously classified as class A have been reclassified as class $B$ areas. Furthermore, in the Marche region, class A areas have been reduced from 39 to 16. Some authors focused on the intermittent faecal contamination sources that may cause a seasonal trend of $E$. coli contamination (Campos et al., 2013), depending mostly on the weather (Ritter et al., 2002), but also on the death rate of $E$. coli in sea water (Fujioka et al., 1981; Kim and Hur, 2010; Rozen and Belkin, 2001; Troussellier et al., 1998). Recently, in the same district of San Benedetto del Tronto, a statistically significant relationship between rainfall and $E$. coli values exceeding the food safety criteria for direct human consumption [ $>230$ most probable number (MPN)/100 g] has been demonstrated, particularly in areas with the highest density of inhabitants (Ciccarelli et al., 2012). Nevertheless, very little is known in literature about seasonal contamination in Italy. The aim of this study was to verify, by means of a statistical test, the seasonal trend of $E$. coli contamination monitored in the natural beds of clams in the district above mentioned.

\section{Materials and Methods}

We analysed the results of the monitoring of E. coli levels in the classified areas of the district of San Benedetto del Tronto (Figure 1) from 2005 to 2012, provided by Algaeadria database, a monitoring network for the whole Adriatic area in order to collect and process homogeneous information on biotoxins, microbiological and phytoplankton (http://algaeadria.org). Results are referred to two established sampling sites in each classified area: the first site (I) was $0.6-0.7 \mathrm{~km}$ offshore, $3-6 \mathrm{~m}$ deep; and the second site (II) was $1.2-1.3 \mathrm{~km}$ offshore, 6-9 m deep. In general, samples were collected quarterly, but during early years they were collected 4-monthly and later, bimonthly.

Microbial analyses were performed by the Veterinary Public Health Laboratory of Marche and Umbria, Fermo office, with the in force MPN method. By graphical data analysis tools (Helsel and Hirsch, 2002), two classes of results were recognised: compliant, if values were $\leq 230 \mathrm{MPN} / 100 \mathrm{~g}$, and non-compliant, if values were $>230 \mathrm{MPN} / 100 \mathrm{~g}$, whose rates and
Correspondence: Cesare Ciccarelli, Servizio Veterinario di Igiene degli Alimenti di Origine Animale - ASUR Marche, Area Vasta n. 5, piazza Nardone 19, 63074 San Benedetto del Tronto (AP), Italy.

Tel. +39.0735 .7937474 - Fax: +39.0735 .793529 .

E-mail: cesare.ciccarelli@sanita.marche.it

Key words: Clams, Chamelea gallina, Escherichia coli, Bivalve monitoring, Seasonality.

Received for publication: 7 May 2013.

Revision received: 31 October 2013.

Accepted for publication: 31 October 2013.

This work is licensed under a Creative Commons Attribution 3.0 License (by-nc 3.0).

(C) Copyright C. Ciccarelli et al., 2014

Licensee PAGEPress, Italy

Italian Journal of Food Safety 2014; 3:1645

doi:10.4081/ijfs.2014.1645

monthly distribution were evaluated. Focusing on that (Figure 2), data were related at three different periods: January-June and JulyDecember (combination A: 6 months and 6 months); March-September and OctoberFebruary (combination B: 7 months and 5 months); March-June and July-February (combination C: 4 months and 8 months). The noncompliant rates were evaluated at each site and each seasonal combination as mentioned above (Figure 3). Furthermore, non-parametric Fisher's exact test was applied to data from each sampling site: the columns of the $2 \times 2$ contingency tables were the compliant and noncompliant values; the lines were values in the first period of time and in the second one for each combination (Table 1). Bonferroni correction method for multiple tests was considered.

\section{Results}

Despite an irregular trend during the year, the non-compliant values of $E$. coli appeared to increase in the early half of the year, as shown in Figure 2. Indeed, the rates of non-compliant values were higher in the first period of speculated combinations than those in the second period, as in Figure 3. As regards the results of Fisher's exact test, shown in Table 1, only for the site 19.02-I (Figure 1) P values seemingly confirmed that the rates of non-compliant values from March to June (combination C) were significantly higher than those from July to February $(\mathrm{P}=0.043)$. Nevertheless, if the Bonferroni correction method for multiple tests is applied, the comparisonwise rate gets $\mathrm{P} \leq 0.016(\mathrm{P} \leq \alpha / \mathrm{k}$ with $\mathrm{k}=3)$, so none of $\mathrm{P}$ values rejected the null hypothesis. 
Table 1. Outcomes of the Fisher's exact test: $P$ values.

\begin{tabular}{lccccccccccccc} 
Combination & & \multicolumn{1}{c}{ Harvesting areas } \\
& $19.01-$ I & $19.01-$ II & $19.02-$ I & $19.02-$ II & $19.03-$ I & $19.03-$ II & $19.04-$ I & $19.04-$ II & $19.05-$ I & $19.05-$ II & R-I & R-II \\
(A) & 0.150 & 0.512 & 0.128 & 0.285 & 0.219 & 0.179 & 0.305 & 0.109 & 0.402 & 0.316 & 0.294 & 0.251 \\
\hline (B) & 0.215 & 0.096 & 0.124 & 0.094 & 0.430 & 0.174 & 0.313 & 0.337 & 0.454 & 0.338 & 0.062 & 0.233 \\
(C) & 0.171 & 0.400 & $0.043^{*}$ & 0.172 & 0.335 & 0.256 & 0.334 & 0.158 & 0.378 & 0.282 & 0.307 & 0.127 \\
\hline
\end{tabular}

*Significant difference $(\mathrm{P}<0.05)$ without Bonferroni correction.

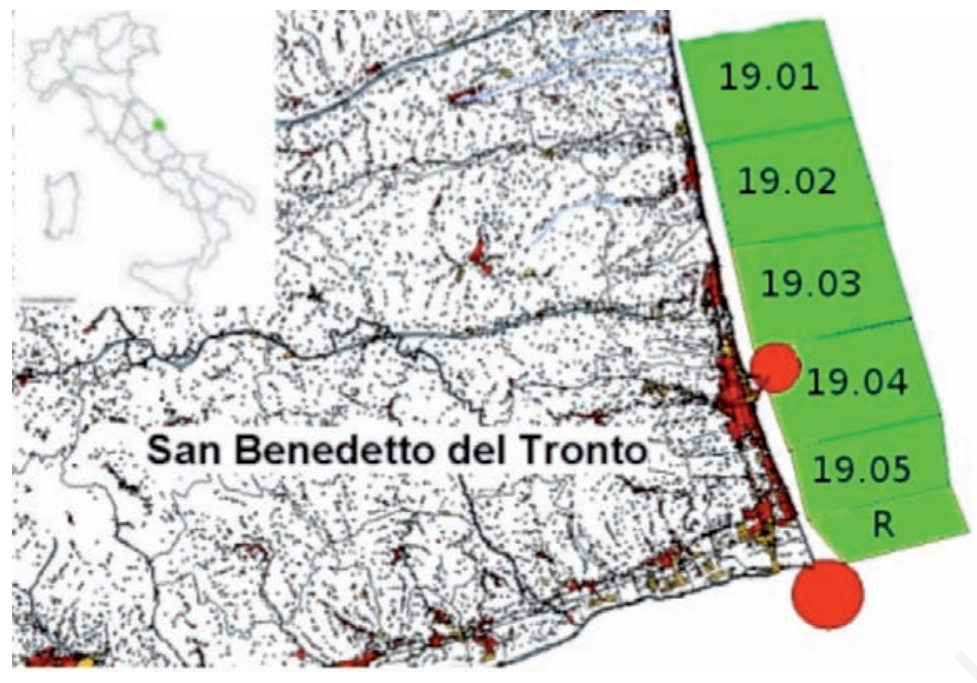

Figure 1. Position of harvesting areas.

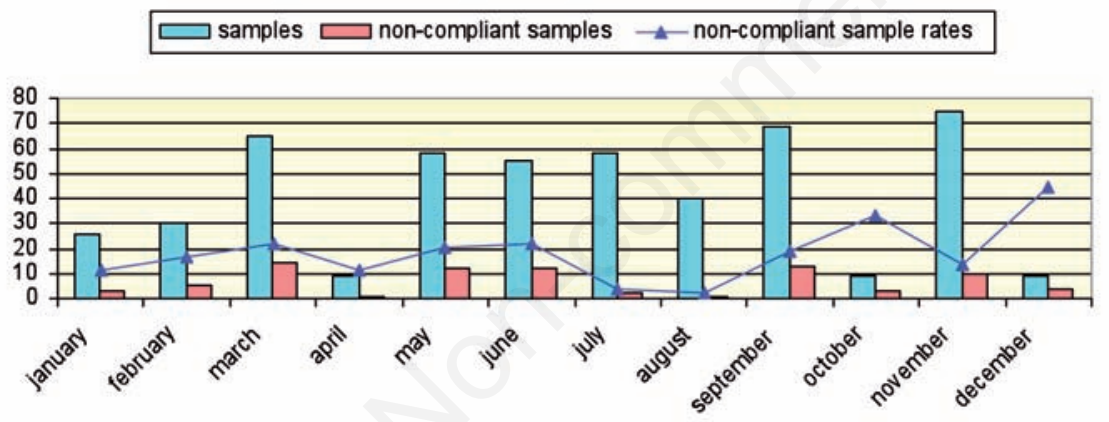

Figure 2. Distribution of results: number of samples, number of non-compliant samples and their rates.

$\square(A)$ jan-jun $\square(A)$ jul-dec $\square(B)$ mar-sep $\square(B)$ oct-feb $\square(C)$ mar-jun $\square(C)$ jul-feb

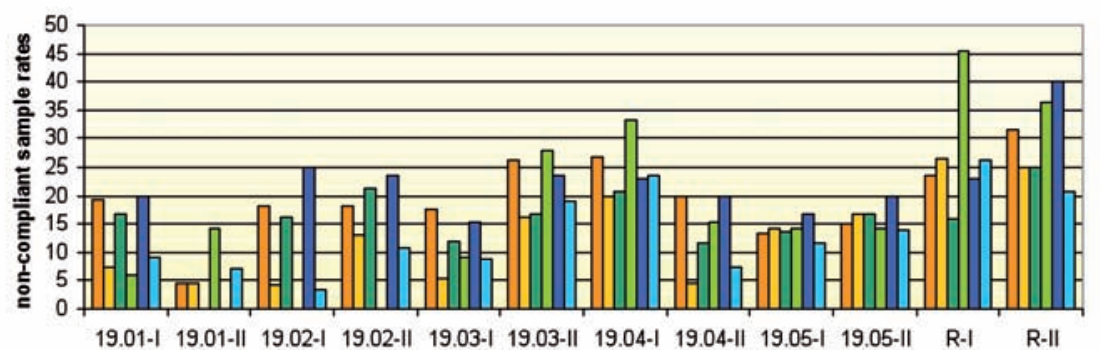

Figure 3. Relationship between non-compliant sample rates and speculated seasonal combinations.

\section{Discussion}

The graphical analysis revealed, first of all, that $E$. coli had an irregular trend during the year in general, with spikes in early months. This could be due to the local distribution of precipitations (Ciccarelli et al., 2012). In effect, by the comparison of the rates of noncompliant results in different seasonal combinations, we found that they significantly increased, in particular, for combination B, from March to September, and, for combination C, from March to June. This may allow a seasonal reclassification of the clam harvesting areas. However, only for one sampling site (19.02-I) and for combination C, the different rates appeared to have statistical significance, when the Bonferroni correction is not applied. This evidence could scientifically support a seasonal classification of production areas and could allow a more detailed classification due to the identification of the periods of time, during the year, with the lowest microbial levels.

\section{Conclusions}

Intermittent faecal contamination sources may critically affect $E$. coli levels in shellfish. Graphical data analysis may reveal seasonal occurrence of exceeding $E$. coli values. Statistical tools, such as non-parametric Fisher's exact test, help to point out the significance of seasonal trends of $E$. coli contamination in shellfish. In effect, by the use of these methods, our study verified the seasonality of non-compliant values with a statistical significance. Finally, it is intended to give a new scientific based support to competent authorities for seasonal classifications of bivalve mollusc harvesting areas and place on the market shellfish products meeting the requirements for direct human consumption.

\section{References}

Campos CJA, Acornley R, Morgan OC, Kershaw $\mathrm{S}, 2013$. Trends in the levels of Escherichia 
coli in commercial harvested bivalve shelIfish from England and Wales, 1999-2008. Mar Pollut Bull 67:223-7.

Ciccarelli C, Semeraro AM, Aliventi A, Di Trani V, Capocasa P, 2012. [Valutazione dell'impatto delle precipitazioni sulla contaminazione fecale delle vongole (Chamelea gallina) raccolte nel distretto di San Benedetto del Tronto (AP)]. [Article in Italian]. Ital J Food Safety 1:46-9.

European Commission, 2004. Regulation of the European Parliament and of the Council of 29 April 2004 laying down specific rules for the organisation of official controls on products of animal origin intended for human consumption, 853/2004/EC. In: Official Journal, L 139, $30 / 04 / 2004$.
Fujioka RS, Hashimoto HH, Siwak EB, Young RHF, 1981. Effect of sunlight on survival of indicator bacteria in seawater. Appl Environ Microb 41:690-6.

Helsel DR, Hirsch RM, 2002. Hydrologic analysis and interpretation: statistical methods in water resources. Available from: http://pubs.usgs.gov/twri/twri4a3/\#pdf

Kim G, Hur J, 2010. Mortality rates of pathogen indicators microorganisms discharged from point and non point sources in an urban area. J Environ Sci 22:929-33.

Marche Region, 2013. [Deliberazione della Giunta Regionale Marche N. 136 del 18/02/2013. Revisione della classificazione sanitaria delle zone di produzione dei molluschi bivalvi vivi ai sensi del Reg. CE/854/2004, approvata con DGRM n.
1300/2009]. [Regulation in Italian]. In: Official Bullettin of Marche Region, L 14, 8/3/2013, pp 3418-41.

Ritter L, Solomon K, Sibley P, Hall K, Keen P, Mattu G, Linton G, 2002. Sources, pathways and relative risks of contaminants in surface water and groundwater: a perspective prepared for the Walkerton inquiry. Jpn J Tox Env Health A 65:1-142.

Rozen Y, Belkin S, 2001. Survival of enteric bacteria in seawater. FEMS Microbiol Rev 25:513-9.

Troussellier M, Bonnefont J-L, Courties C, Derrien A, Dupray E, Gauthier M, Gourmelon M, Joux F, Lebaron P, Martin Y, Pommepuy M, 1998. Reponses of enteric bacteria to environmental stresses in seawater. Oceanol Acta 21:968-81. 